\title{
Soil Water Characteristics of Gleysols in the Bamenda (Cameroon) Wetlands and Implications for Agricultural Management Strategies
}

\author{
Alice Mufur Magha, ${ }^{1}$ Primus Azinwi Tamfuh ${ }^{(D)},{ }^{2,3}$ Lionelle Estelle Mamdem, ${ }^{4}$ \\ Marie Christy Shey Yefon, ${ }^{3}$ Bertrand Kenzong, ${ }^{2}$ and Dieudonné Bitom ${ }^{2}$ \\ ${ }^{1}$ Department of Geology, Higher Teacher Training College, The University of Bamenda, P.O. Box 39, Bambili, Cameroon \\ ${ }^{2}$ Department of Soil Science, University of Dschang, P.O. Box 222, Dschang, Cameroon \\ ${ }^{3}$ Department of Mining and Mineral Engineering, National Higher Polytechnic Institute, University of Bamenda, P.O. Box 39, \\ Bambili, Cameroon \\ ${ }^{4}$ Department of Earth Sciences, University of Ngaoundéré, P.O. Box 454, Ngaoundéré, Cameroon
}

Correspondence should be addressed to Primus Azinwi Tamfuh; aprimus20@yahoo.co.uk

Received 28 November 2020; Revised 23 February 2021; Accepted 27 February 2021; Published 13 March 2021

Academic Editor: Evgeny Abakumov

Copyright $\odot 2021$ Alice Mufur Magha et al. This is an open access article distributed under the Creative Commons Attribution License, which permits unrestricted use, distribution, and reproduction in any medium, provided the original work is properly cited.

\begin{abstract}
Water budgeting in agriculture requires local soil moisture information as crops depend mainly on moisture available at root level. The present paper aims to evaluate the soil moisture characteristics of Gleysols in the Bamenda (Cameroon) wetlands and to evaluate the link between soil moisture content and selected soil characteristics affecting crop production. The work was conducted in the field and laboratory, and data were analyzed by simple descriptive statistics. The main results showed that the soils had a silty clayey to clayey texture, high bulk density, high soil organic carbon content, and high soil organic carbon stocks. The big difference between moisture contents at wilting point and at field capacity testified to very high plant-available water content. Also, the soils displayed very high contents of readily available water and water storage contents. The soil moisture characteristics give sigmoid curves and enabled noting that the Gleysols attain their full water saturation at a range of 57.68 to $91.70 \%$ of dry soil. Clay and SOC contents show a significant positive correlation with most of the soil moisture characteristics, indicating that these soil properties are important for soil water retention. Particle density, coarse fragments, and sand contents correlated negatively with the soil moisture characteristics, suggesting that they decrease soil water-holding capacity. The principal component analysis (PCA) enabled reducing 17 variables described to only three principal components (PCs) explaining $73.73 \%$ of the total variance; the first PC alone expressed $45.12 \%$ of the total variance, associating clay, SOC, and six soil moisture characteristics, thus portraying a deep correlation between these eight variables. Construction of contoured ditches, deep tillage, and raised ridges management techniques during the rainy season while channeling water from nearby water bodies into the farmland, opportunity cropping, and usage of water cans and other irrigation strategies are used during the dry season to combat water constraints.
\end{abstract}

\section{Introduction}

Soil water information is necessary for rainfall partition, establishment of irrigation schedules, and partitioning of net radiation $[1,2]$. The response of soil water properties is a key indicator of the impact of agricultural management on the movement of water and chemicals through the soil [3].
Wetlands are temporarily or permanently flooded areas where the soils are water-saturated and waterlogging is common [4].

Gleysols, typical of wetlands, are characterized by reduction or localized segregation of iron, due to temporary or permanent waterlogging causing anaerobic conditions [5]. These soils occur where hydrological conditions controlled 
by abundant rainfall, gentle slope, low landscape position, or impermeable soils lead to soil surface saturation by water for a sufficiently long period enough for waterlogging to occur [6]. Water fluctuations at depths control the chemical and/or biological processes within both the water column and soil particles $[7,8]$. Wetland soils are unique among soils and possess morphological, physical, and chemical properties that readily distinguish them from upland soils $[9,10]$. Considerable studies have been carried out to understand the moisture characteristics of tropical soils [11-13]. However, little effort has been dedicated to the understanding of Gleysols water characteristics in tropical wetland ecosystems.

Wetlands cover approximately $6 \%$ of the Earth's surface in all climates [12]. Although these wetland soils may be minor inclusions in terms of their spatial distribution, they are important contributors to agricultural productivity [5]. These areas contain about 35\% of global terrestrial carbon critical to agricultural production and climate change mitigation [14]. The Ramsar Convention on Wetland Protection [4] highlights key information on wetlands and climate change mitigation and adaptation such as the assessment of carbon uptake and storage. This has revealed that continuous loss and degradation of wetlands results in significant losses of soil organic carbon stock (SOCS) to the atmosphere [14].

According to the Ramsar Sites Information Service [15], there are seven Ramsar sites in Cameroon (The BarombiMbo Crater Lake, the Rio Del Rey Estuaries, Cameroonian section of the Ntem River, Cameroonian Section of the Sangha River, Cameroonian section of the Lake Chad, Waza-Logone floodplain, and the Ebogo Humid Zone) covering a total surface area of $8270.6 \mathrm{~km}^{2}$. The positions of the sites are shown in Figure 1. Many Cameroonian vast wetlands have not yet been studied in detail and thus remain unselected as Ramsar sites such as the Limbe and Wouri estuaries (Littoral Cameroon), the Nun River valley, the Menchum/Mezam Valley (Northwest Cameroon), the Santchou Floodplains (West Cameroon), amongst others. The study and selection of these wetlands as Ramsar Sites in Cameroon could contribute to one of the goals of the Ramsar Convention's strategic plan [4], which was to attain a protected area of 250 million hectares since 2015.

In Bamenda Town (Northwest Cameroon), major wetlands occur along the Mezam River floodplains and its tributaries especially in Ngomgham, Mulang, Ntenefor, Below Foncha, and Mile 4 Nkwen [15-17]. The lawless occupation of wetlands has intensified recently due to demographic pressure as soils in these areas are very fertile and support year-round market gardening $[18,19]$. Some human activities in these wetlands (land reclamation, waste disposal, deforestation, agriculture, industrialization, etc.) have led to the degradation of most of these ecosystems [20].

The main agricultural practice in Bamenda wetlands is market gardening and dry season maize farming [21]. In these wetland soils, Asongwe et al. [21] reported the spatial variability of physicochemical properties of soils under vegetable. Mofor et al. [22] focused on trace element status and environmental implications on soils and
Zea mays near dumpsites. Land preparation for crop production is conducted under submerged conditions generating a massive plough layer which affects management strategies and crop performance. Works that concern the moisture characteristics of those Gleysols are inexistent despite the fact that soil water is the major factor affecting agriculture in these areas. Some question thus require answers: what are the moisture characteristics of the Bamenda wetland soils; is there a relationship between the moisture characteristics and the other soil properties; what are the best management strategies of the soils for sustainable agriculture?

The aim of the present study was to determine the moisture characteristics of the Bamenda Gleysols and to establish a link between moisture characteristics and selected soil characteristics, as well as to recommend best management strategies of the Gleysols for crop production. The results obtained will enable to support the conservation, restoration, and management of wetland soils and to create social awareness on the importance of wetlands in line with one of the goals of the Ramsar Convention's strategic plan.

\section{Materials and Methods}

2.1. Study Site Description. The Bamenda municipality is located on the northwest flank of the Bamenda Mountain which is a stratovolcano situated along the Cameroon Volcanic Line $[23,24]$. It extends from longitude $10^{\circ} 08^{\prime}$ to $10^{\circ} 12^{\prime} \mathrm{E}$ and latitude $5^{\circ} 55^{\prime}$ to $6^{\circ} 00^{\prime} \mathrm{N}$ and at an altitude of $2621 \mathrm{~m}$ above sea level (Figure 2 ). The town covers a surface area of $71.23 \mathrm{~km}^{2}$. The climate is the Cameroonian-type equatorial climate characterized by two seasons: a long rainy season of 7 months (April to October) and a short dry season of 5 months (November to March). The mean annual rainfall is $2670 \mathrm{~mm}$ and the average annual air temperature is $25^{\circ} \mathrm{C}$. The Mezam River draining the town is a second-order perennial stream fed by several other small streams, most of which originate from the Bamenda escarpments. They form a dense dendritic pattern. The major winds affecting this area are Harmattan (that bring the dry season) and the monsoon (that brings rain). Rainfall is heavy and often destructive. The vegetation is the Guinea Savannah type with short stunted trees (Bamenda Grassfields) and short deciduous trees; meanwhile Raffia palms grow in the swampy valleys. The town is located along the Cameroon Volcanic Line and exhibits two very distinct relief environments: the high lava plateau or Up Station (1400 m above sea level) and the low plateau or Downtown (1200 m above sea level), separated by an escarpment of about $150 \mathrm{~m}$. Geologically, Bamenda is underlain by Precambrian granite-gneiss basement, and overlain by volcanic rocks like basalts, trachyte, dolerite, and ignimbrites [25], sedimentary silty clays of the Mezam River floodplains [26]. The dominant soils are Ferralsols with minor Lithosols on the hillslopes and Gleysols in the swampy valleys $[9,21]$. Farming is the main activity of the inhabitants and it is mostly crop-based farming, pastoral nomadism, mixed crop-livestock, and secondary and tertiary activities [21]. 


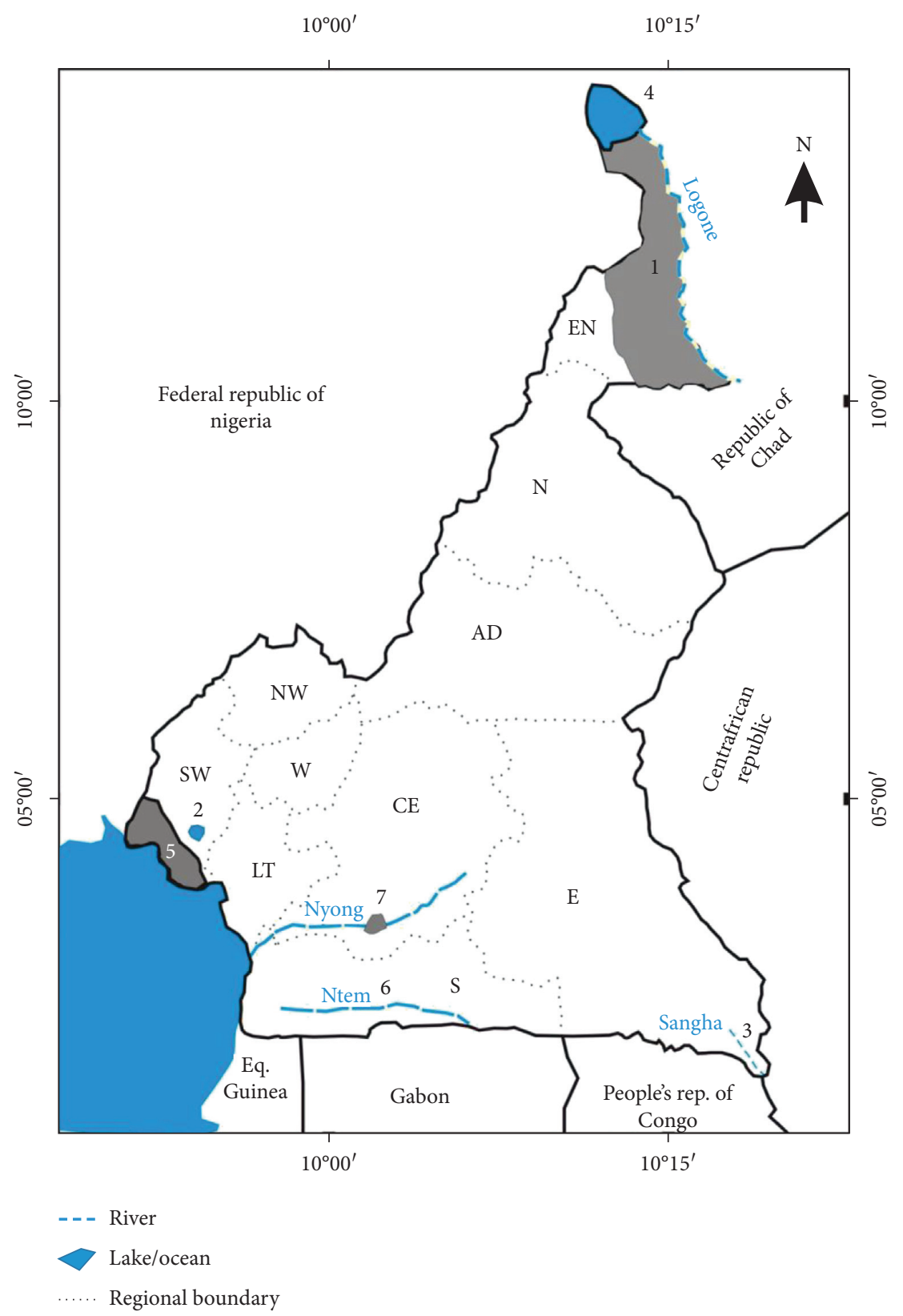

Figure 1: Location of the Ramsar sites in Cameroon [15]. Sites are numbered from youngest to oldest based designation date. (1) WazaLogone floodplain; (2) Barombi-Mbo Lake; (3) Cameroon section of the Sangha River; (4) Cameroon section of Lake Chad; (5) Rio Del Rey Estuary; (6) Cameroon section of the Ntem River; (7) Ebogo Humid Zone; EN: Extreme North Region; NW: Northwest Region; N: North Region; AD: Adamawa Region; CE: Centre Region; E: East Region; LT: Littoral Region; S: South Region; SW: Southwest Region; W: West Region.

2.2. Methodology and Analytics. Twenty (20) sampling points, representative of the Bamenda Wetlands, were selected within five neighborhoods (Mulang, Ngomgham, Below Foncha, and Mile 4 Nkwen) in the Bamenda municipality wetlands (Figure 2). One sample was collected per point at $0-50 \mathrm{~cm}$ depth (effective rooting zone for a majority of crops cultivated in this area: green beans, onion, licks, huckleberry, tomatoes, carrot, etc.). Disturbed and undisturbed samples were taken for three repetitions. The total area sampled was about $30 \mathrm{~km}^{2}$. Sampling was conducted in the dry season in November 2019 when the water level in the area was low. Soil samples collected were packed in air-tied plastic bags and taken to the laboratory for analysis.

In the laboratory, the bulk density $\left(D_{b}\right)$ was determined by paraffin coating method and particle density $\left(D_{p}\right)$ was measured by pycnometer method. Porosity $(p)$ was deduced from the particle and bulk densities. The particle size distribution was measured by Robinson's pipette method and 

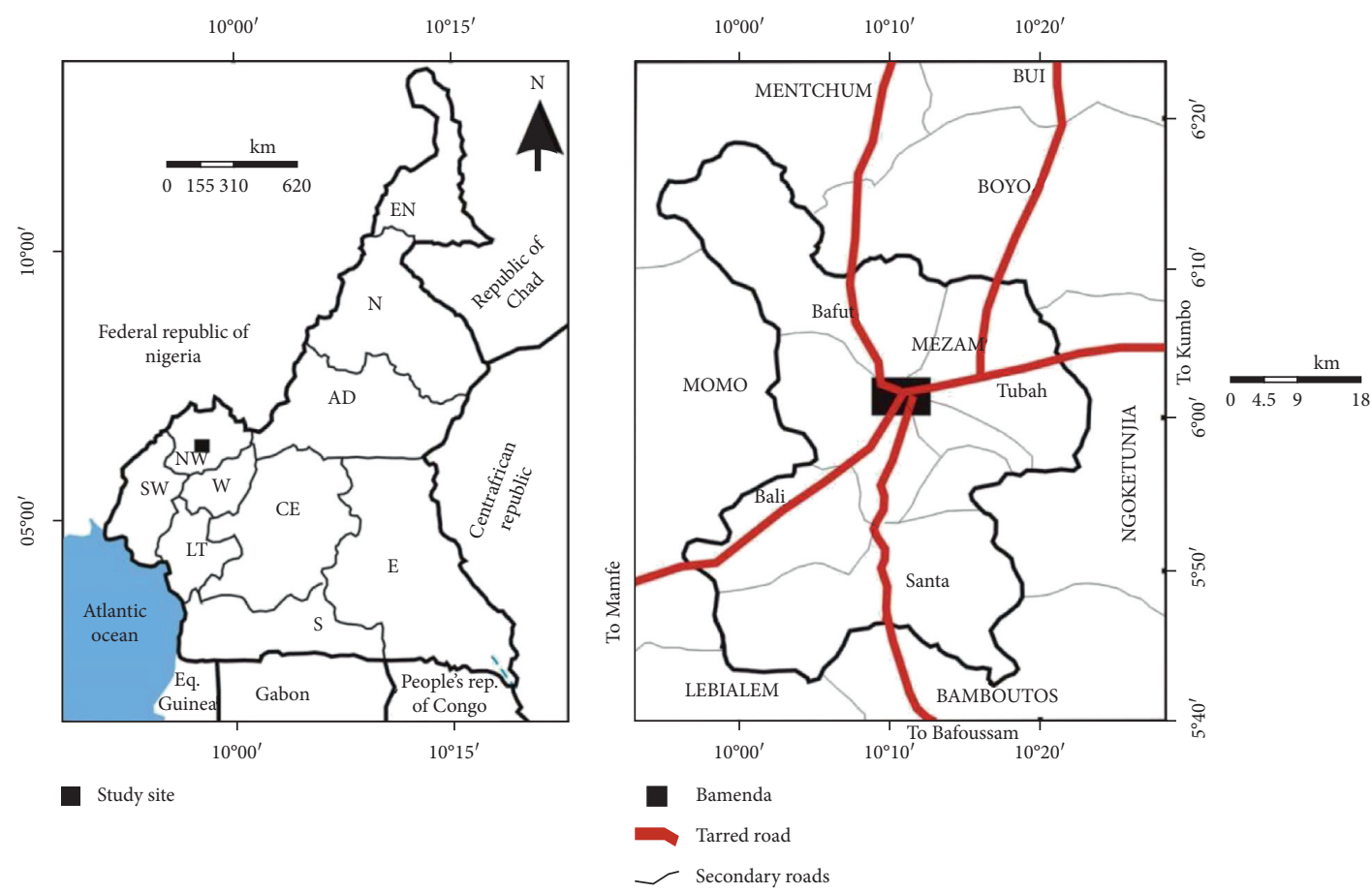

(a)

(b)

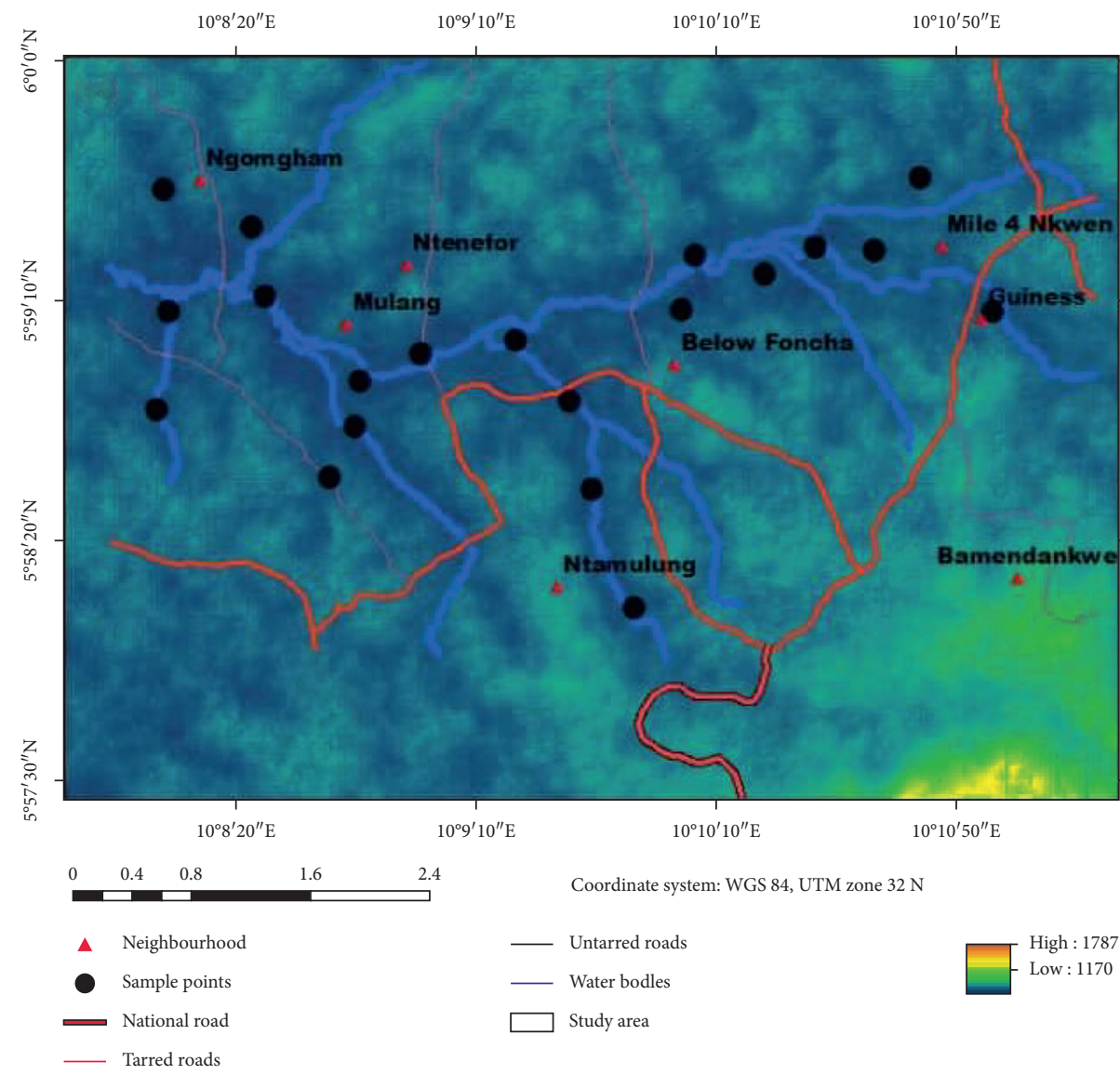

(c)

Figure 2: Location maps of the study area: (a) location of Mezam Division in Cameroon; (b) location of Bamenda in Mezam Division; (c) studied site map with sampling points. 
SOC was analyzed by Walkley-Black method. All these analyses were conducted according to the procedures described in [27].

The soil organic carbon stock (SOCS) was calculated according to the following equation [14]:

$$
\begin{aligned}
\operatorname{SOCS}\left(\mathrm{Mg} \cdot \mathrm{ha}^{-1}\right)= & (\text { SOC content } \times \mathrm{BD} \times d \\
& \left.\times\left(1-\delta_{2 \mathrm{~mm}} \%\right) \times 10\right),
\end{aligned}
$$

where SOC is the organic carbon content $\left(\mathrm{g} \mathrm{kg}^{-1}\right), d$ is the soil layer thickness $(\mathrm{m}), \delta_{2 \mathrm{~mm}}$ is the coarse fragments ( $>2 \mathrm{~mm}$ diameter) content (\%), and $\mathrm{BD}$ is the soil bulk density $\left(\mathrm{Mg} \cdot \mathrm{m}^{-3}\right)$.

The hygroscopic water content was calculated by using the weight loss of an air-dry sample, after subjecting it to an oven temperature of $105^{\circ} \mathrm{C}$ for 24 hours [28]. To determine the soil water content at field capacity (FC), the soil cores were first saturated and their soil water content at $33 \mathrm{kPa}$ was measured using the tension tables [29]. The permanent wilting point (WP) water content at $1500 \mathrm{kPa}$ suction was measured on the subsample using a pressure plate apparatus [30]. The capillary water (CW) was calculated as the difference between the hygroscopic water and the field capacity water content [31]. The unavailable water content (UW) was obtained as the difference between the capillary water and water content permanent wilting point [32]. Gravity water (GW) was obtained as the difference between total porosity and capillary water. The air content (AC) was calculated as the difference between the total porosity and the moisture content at field capacity [5]. The available water reserve (AWR) was calculated as the difference between the FC and WP [33].

The available water content (AWC) was calculated according to the following equation [5]:

$$
\mathrm{AWC}=\left(\frac{D_{b} \times E \times(\mathrm{FC}-\mathrm{WP})}{100}\right),
$$

where FC is the moisture content at field capacity (\%), WP is the moisture content at permanent wilting point (\%), $E$ is the depth of the soil layer (in $\mathrm{dm}$ ), and $D_{b}$ is the soil bulk density in $\mathrm{g} \cdot \mathrm{cm}^{-3}$.

The readily available water content (RAW) was estimated as the product of the management allowed deficiency (approximately $2 / 3$ for wetland soils) and the AWC [32]:

The water-holding capacity (WHC) was calculated as the AWC multiplied by 2 according to GEPPA [34].

Before calculating the infiltration depth (in $\mathrm{dm} \cdot \mathrm{m}^{-1}$ ) in each of the soil layers, the volumetric water content was calculated according to the following equation [35]:

$$
V_{w}=\mathrm{FC} \cdot\left(\frac{D_{b}}{D_{w}}\right)
$$

where $V_{w}$ is the volumetric water content (at field capacity) in, FC is the gravimetric water content at field capacity, $D_{b}$ is the soil bulk density, and $D_{w}$ is the density of water $\left(1 \mathrm{~g} \cdot \mathrm{cm}^{-3}\right)$. The infiltration depth of the soil layer was then obtained as the product of $V_{w}$ and the soil depth (in $\mathrm{dm}$ ) [35].
2.3. Statistical Analyses. Pearson linear correlation test and principal component analysis (PCA) enabled establishing the relationship between soil characteristics.

\section{Results}

3.1. Soil Characteristics. The characteristics of the Bamenda Gleysols sampled in the five different neighborhoods are compiled in Table 1; meanwhile, results of summary statistical analysis of these soil characteristics are presented in Table 2. Soil characteristics such as particle density, bulk density, total porosity, and particle distribution did not vary much amongst the different sites. The SOC and SOCS were also very high for all the studied sites, but the ranges of values amongst the different sites differed very lightly (Table 1). The particle density of the soils ranged between 2.3 and $2.5 \mathrm{~g} \cdot \mathrm{cm}^{-3}$, with a mean of $2.36 \mathrm{~g} \cdot \mathrm{cm}^{-3}$, and a very low coefficient of variation (CV) of $2.86 \%$ (Table 2). About $45 \%$ of the samples showed a low particle density of $2.3 \mathrm{~g} / \mathrm{cm}^{3}$ while the rest ranged from 2.4 to $2.5 \mathrm{~g} \cdot \mathrm{cm}^{-3}$. The bulk density ranged from 1.3 to $1.6 \mathrm{~g} \cdot \mathrm{cm}^{-3}$, with a mean of $1.43 \mathrm{~g} \mathrm{~cm}^{-3}$ and a very low $\mathrm{CV}$. The total porosity varied from 40 to $43.48 \%$, with a mean of $41.67 \%$ and changed very little from one locality to another $(\mathrm{CV}=3.0 \%)$. The soils showed only two grain size classes: clayey to clayey loam texture (Figure 3). The clayey fraction was moderately variable $(\mathrm{CV}=21.0 \%)$, and $90.0 \%$ of the values fell between 30 and $45.0 \%$ clay content. The fine silt contents ranged from 8.0 to $29.0 \%$, with a high CV. The coarse silt contents ranged from 10.0 to $22.0 \%$, with an average of $17.90 \%$ and a moderate CV. The fine sand fraction varied from 6.0 to $22.0 \%$, with a mean of $13.6 \%$ and a CV of $32.0 \%$. The coarse sand content followed almost the same trend as fine sand, ranging from 9 to $22 \%$, giving a mean of $15.1 \%$ and CV of $29 \%$. The contents in coarse fragment varied from 3 to $25 \%$, with an average value of $12 \%$ and a high CV. The sand/silt ratio fluctuated between 0.55 and 1.96 , portraying a moderate coefficient of variation of $34 \%$. The silt/clay ratio varied between 0.55 and 1.90 , with a low CV of $10.5 \%$. The (silt + sand)-to-total earth ratios of the Gleysols ranged between 52.29 and $75.73 \%$. The SOC fluctuated from 5.67 to $19.45 \%$, with an average of $13.66 \%$ and a CV of $30.32 \%$. The SOCS varied between 251.63 and $804.93 \mathrm{Mg} \cdot \mathrm{ha}^{-1}$ with a mean of $553.30 \mathrm{Mg} \cdot \mathrm{ha}^{-1}$ and a moderate $\mathrm{CV}$.

The soil moisture characteristics are compiled in Table 3 and the results of summary statistical analysis of moisture retention characteristics are presented in Table 4 . The hygroscopic water content varied between 7.20 and $23.03 \%$, with a mean of $13.72 \%$ and $\mathrm{CV}$ of $36.0 \%$. The $\mathrm{WP}(\mathrm{pF} 3=1500 \mathrm{kPa})$ ranged between 22.14 and $58.86 \%$, with a mean of $44.8 \%$ and CV of $25.0 \%$. The moisture content at field capacity $\mathrm{FC}(\mathrm{pF} 3=33 \mathrm{kPa})$ changed between 48.16 and $75.34 \%$, showing a mean of $67.0 \%$ and a CV of $11.0 \%$. The AWR ranged between $11.13 \%$ and $45.8 \%$; its mean value stood at $22.2 \%$ and the CV was $46.0 \%$. The AWC of the studied soil varied between 215.83 and $423.61 \mathrm{~mm} / \mathrm{m}$, with a mean value of 339.7 and a CV of $18.0 \%$. The RAW varied from 289.21 to $567.64 \mathrm{~mm} / \mathrm{m}$, with a mean of 455.40 and a CV of $18.0 \%$. The CW was within the range of 29.04 to $57.0 \%$ and the most frequent values appeared between 39 and $57.0 \%$, while the 


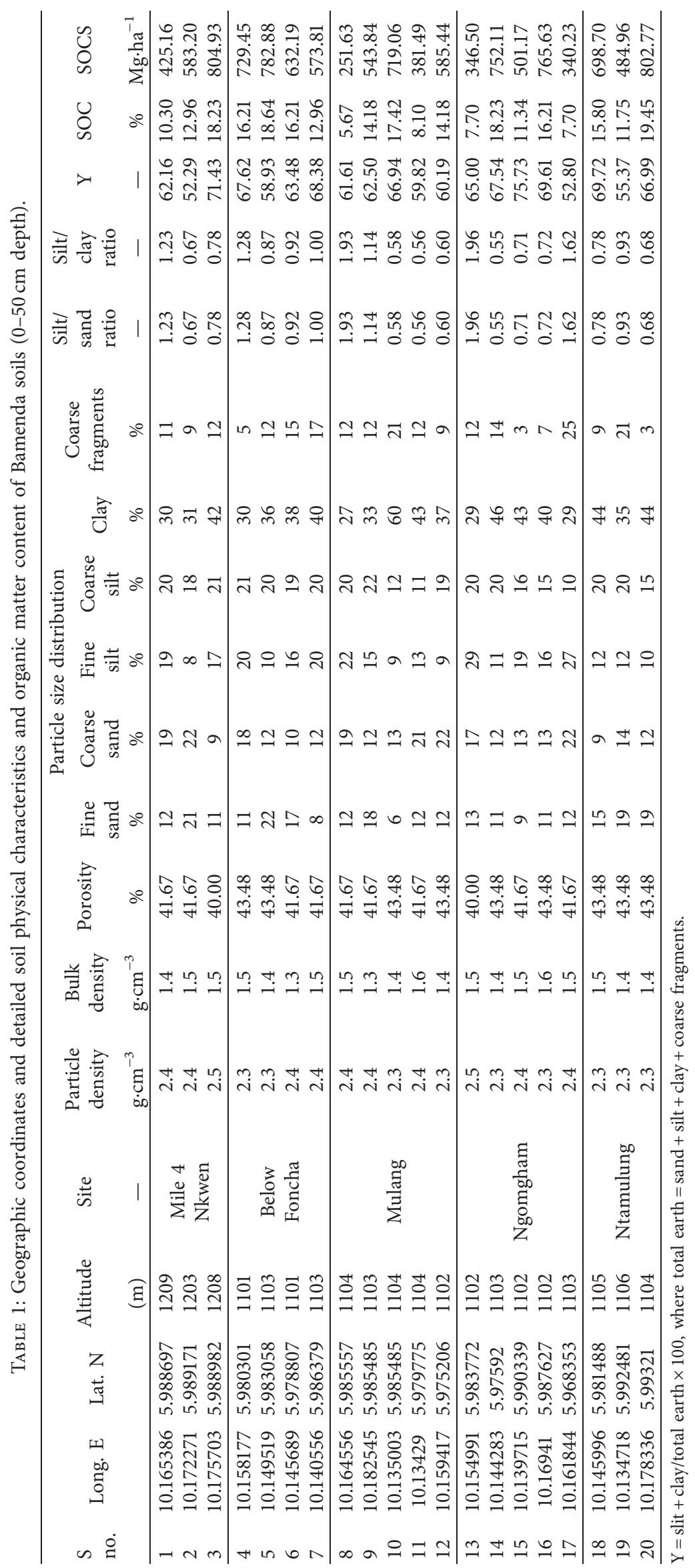


TABLe 2: Summary statistics of the soil physical characteristics and organic matter content $(n=20)$.

\begin{tabular}{|c|c|c|c|c|c|c|c|c|c|c|c|c|c|}
\hline \multirow{3}{*}{ Parameters } & \multirow{3}{*}{$\begin{array}{c}D_{p} \\
\mathrm{~g} \cdot \mathrm{cm}^{-3}\end{array}$} & \multirow{3}{*}{$\begin{array}{c}D_{b} \\
\mathrm{~g} \cdot \mathrm{cm}^{-3}\end{array}$} & \multirow{3}{*}{$\begin{array}{c}\text { Porosity } \\
\quad \% \\
\end{array}$} & \multicolumn{5}{|c|}{ Particle size distribution } & \multirow{3}{*}{$\begin{array}{c}\text { Coarse } \\
\text { fragments } \\
\%\end{array}$} & \multirow{3}{*}{$\begin{array}{c}\text { Sand/silt } \\
\text { ratio } \\
\%\end{array}$} & \multirow{3}{*}{$\begin{array}{c}\text { Silt/ } \\
\text { clay } \\
\text { ratio } \\
\%\end{array}$} & \multirow{3}{*}{$\begin{array}{c}\text { SOC } \\
\% \\
\end{array}$} & \multirow{3}{*}{$\begin{array}{c}\text { SOCS } \\
\text { Mg.ha }\end{array}$} \\
\hline & & & & $\begin{array}{l}\text { Fine } \\
\text { sand }\end{array}$ & $\begin{array}{c}\text { Coarse } \\
\text { sand }\end{array}$ & $\begin{array}{l}\text { Fine } \\
\text { silt }\end{array}$ & $\begin{array}{l}\text { Coarse } \\
\text { silt }\end{array}$ & Clay & & & & & \\
\hline & & & & $\%$ & $\%$ & $\%$ & $\%$ & $\%$ & & & & & \\
\hline & & 120 & & 6.00 & 000 & 00 & 10.00 & 7 & & & 0.55 & 5.67 & 251.63 \\
\hline Maxi & 2.50 & 50 & 48 & 22.00 & 00 & 29.00 & 22.00 & .00 & & 1. & 1.96 & 19.45 & \\
\hline Mean & 2.36 & 1.45 & 42.32 & 13.60 & 15.10 & 15.70 & 17.90 & 37.90 & 12 & 0. & 0.96 & 13.66 & 593.68 \\
\hline $\mathrm{SD}$ & 0.067 & 0.083 & & & & & 3.55 & 7.92 & & & 0.44 & 4.14 & 172.61 \\
\hline $\mathrm{CV}$ & & & & 32.00 & 29.00 & 38.50 & 19 & 21 & & 34. & 10.5 & 30.32 & 29.07 \\
\hline Skew & 0.549 & -0.176 & -0.464 & 0.477 & 0.400 & 0.720 & -1.197 & 0.957 & 0.521 & 0.99 & 1.390 & -0.450 & -0.52 \\
\hline Kurto & -0.548 & -0.212 & -7.65 & -0.575 & -1.29 & -0.08 & 0.27 & 1.71 & 0.27 & 0.56 & 0.98 & -0.92 & -0.85 \\
\hline K-S stat & 0.284 & 0.257 & 0.287 & 0.238 & 0.226 & 0.133 & 0.269 & 0.119 & 0.203 & 0.122 & 0.210 & 0.147 & 0.282 \\
\hline
\end{tabular}

$D_{p}$ : particle density; $D_{b}$ : bulk density; CV: coefficient of variation; SD: standard deviation; K-S stat: Kolmogorov-Smirnov statistics.

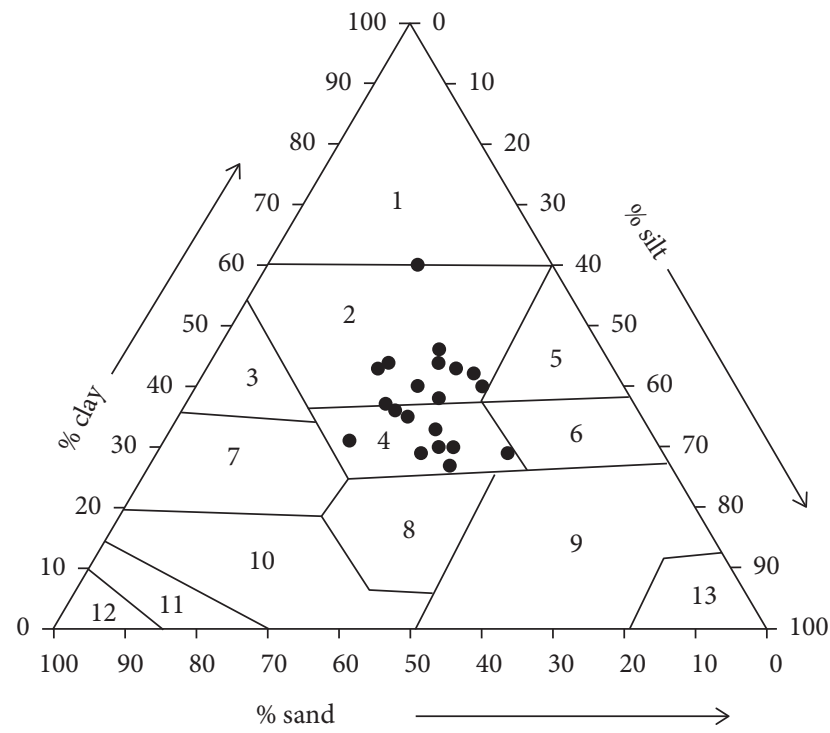

FIGURE 3: Textural classes of the Bamenda Gleysols according to the United States Department of Agriculture textural classification-classification according to the Soil Science Division Staff [6]. (1) heavy clay; (2) clay; (3) sandy clay; (4) clayey loam; (5) silty clayey; (6) silty clay loam; (7) sandy clay loam; (8) loam; (9) silty loam; (10) sandy loam; (11) loamy sand; (12) sand; (13) loam.

mean value stood at $48.08 \%$ and the CV was $14.0 \%$. The UW varied between 2.44 and $27.59 \%$. The mean value of unavailable water of $8.48 \%$ was low showing a low $\mathrm{CV}$ at $5.10 \%$. The WHC varied between 431.71 and $847.22 \mathrm{~mm} / \mathrm{m}$; meanwhile, the mean values attained $679.70 \mathrm{~mm} / \mathrm{m}$ and the $\mathrm{CV}$ was $18 \%$. The gravitational water content of the Bamenda wetland soils ranged from $0.72 \%$ to $13.52 \%$, with a mean of $7.46 \%$ and a CV of 54.71 . The infiltration depth $(D)$ appeared between $2.65 \mathrm{dm} \cdot \mathrm{m}^{-1}$ and $4.44 \mathrm{dm} \cdot \mathrm{m}^{-1}$ and the mean and $\mathrm{CV}$ were, respectively, $3.83 \mathrm{dm} \cdot \mathrm{m}^{-1}$ and $12 \%$. The natural air content of the soils at FC oscillated between 6.49 and $31.86 \%$, with a mean of 24.76 and a CV of $28 \%$.

3.2. Correlation and Principal Component Analysis of the Soil Characteristics. There was a positive correlation between sand content and $D_{p}$ and a negative correlation between $D_{P}$ and clay content (Table 5). $D_{b}$ was correlating negatively with SOC while sand and clay contents showed a significant negative correlation. Clay and SOC contents showed a significant positive correlation. The coarse fragments contents correlated negatively with SOC and $D_{b}$, but positively with $D_{b}$. The silt/clay ratio showed a significant positive correlation with $D_{b}, D_{p}$ as well as sand, silt, and rock fragment contents, but correlated negatively with SOC and clay contents. Among the soil properties, SOCS was positively correlated with $D_{b}$, clay, and silt-to-clay ratio, but negatively correlated with $D_{p}$, sand, silt, coarse fragments, and SOC contents. No significant correlation was observed between the soil moisture characteristics and silt/clay ratio. The SOCS showed a positive correlation with FC, PW, CW, and WHC and a negative correlation with HW, AWR, and UW.

The analysis of linear correlation of soil moisture characteristics revealed that WP showed a significant positive correlation with AWC and RAW and a significant negative correlation with AWR and UW (Table 6). Also, FC showed a positive correlation with AWC, RAW, WHC, and infiltration depth $(D)$ of the soil layer. The AWR showed a very significant negative correlation with AWC, RAW, and WHC. The AWC displayed a strong negative correlation with UW, while RAW displayed a strong negative correlation with UW. The CW revealed a strong positive correlation with $\mathrm{D}$. Also, UW showed a significant negative correlation with WHC.

The PCA enabled observing a reduction of the 17 original variables described to only three principal components (PC1, PC2, and PC3) explaining $73.73 \%$ of the total variance explained (Table 7). Thus, PC1 explained $45.12 \%$ of the total variance and revealed significant loadings on WP, AWR, AWC, RAW, UW, WHC, clay, and SOC, while PC2 expressed $18.93 \%$ of the total variance and showed significant loadings at FC, CW, and D (Figure 4). PC3 expressed significant loadings with $D_{b}$ and sand with a total variance of $9.68 \%$. The PC1 was named the soil water retention factor because of a high factor loading of moisture characteristics with soil colloids (clay and organic carbon). The PC2 was referred to as the available water factor because of high factor loading between available water, capillary water, and infiltration depth. The PC3 was denoted the soil compaction factor as sand and bulk density affect soil porosity. 
TABLE 3: Moisture characteristics of the Gleysols from the Bamenda Wetlands $(n=20)$.

\begin{tabular}{|c|c|c|c|c|c|c|c|c|c|c|c|c|c|}
\hline S no. & Site & $\begin{array}{l}\text { HW } \\
(\%)\end{array}$ & $\begin{array}{l}\text { WP } \\
(\%)\end{array}$ & $\begin{array}{l}\text { FC } \\
(\%)\end{array}$ & $\begin{array}{c}\text { AWR } \\
(\%)\end{array}$ & $\begin{array}{c}\text { AWC } \\
(\mathrm{mm} / \mathrm{m})\end{array}$ & $\begin{array}{c}\text { RAW } \\
(\mathrm{mm} / \mathrm{m})\end{array}$ & $\begin{array}{c}\mathrm{CW} \\
(\mathrm{mm} / \mathrm{m})\end{array}$ & $\begin{array}{c}\text { UW } \\
(\mathrm{mm} / \mathrm{m})\end{array}$ & $\begin{array}{c}\mathrm{GW} \\
(\mathrm{mm} / \mathrm{m})\end{array}$ & $\begin{array}{l}\mathrm{AC} \\
(\%)\end{array}$ & $\begin{array}{c}\text { WHC } \\
(\mathrm{mm} / \mathrm{m})\end{array}$ & $\begin{array}{c}\mathrm{D} \\
(\mathrm{dm} / \mathrm{m})\end{array}$ \\
\hline 1 & & 9.12 & 36.6 & 48.16 & 11.56 & 282.67 & 378.78 & 29.04 & 2.44 & 12.63 & 6.49 & 565.34 & 2.65 \\
\hline 2 & Mile 4 Nkwen & 7.2 & 41.52 & 56.6 & 15.08 & 331.27 & 443.9 & 39.4 & 7.88 & 2.27 & 14.93 & 662.53 & 3.34 \\
\hline 3 & & 8.2 & 56.06 & 67.19 & 11.13 & 418.1 & 560.25 & 46.99 & 2.93 & 6.99 & 27.19 & 836.19 & 3.97 \\
\hline 4 & & 17.76 & 48.42 & 69.8 & 21.38 & 371.64 & 497.99 & 52.04 & 3.62 & 8.56 & 26.32 & 743.27 & 4.12 \\
\hline 5 & & 12.22 & 55.68 & 72.58 & 16.9 & 387.54 & 519.3 & 54.36 & 4.68 & 10.88 & 29.1 & 775.07 & 4 \\
\hline 6 & 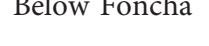 & 22.2 & 47.62 & 73.28 & 25.66 & 317.67 & 425.67 & 51.08 & 3.46 & 9.41 & 31.61 & 635.33 & 3.75 \\
\hline 7 & & 13.4 & 45.92 & 69.41 & 23.49 & 359.32 & 481.48 & 46.01 & 10.09 & 4.34 & 27.74 & 718.63 & 4.1 \\
\hline 8 & & 12.32 & 22.14 & 57.2 & 35.06 & 215.83 & 289.21 & 44.88 & 22.74 & 3.21 & 15.53 & 431.66 & 3.38 \\
\hline 9 & & 10.88 & 45.56 & 62.47 & 16.91 & 308.24 & 413.04 & 45.59 & 6.03 & 3.92 & 20.8 & 616.48 & 3.2 \\
\hline 10 & Mulang & 7.43 & 58.84 & 72.67 & 13.83 & 407.6 & 546.18 & 53.24 & 6.4 & 9.76 & 29.19 & 815.2 & 4.01 \\
\hline 11 & & 15.8 & 33.4 & 70.49 & 37.09 & 303.91 & 407.23 & 54.69 & 21.29 & 13.02 & 28.82 & 607.81 & 4.44 \\
\hline 12 & & 12.21 & 47.16 & 62.62 & 15.46 & 341.47 & 457.57 & 41.41 & 3.25 & 2.07 & 19.14 & 682.94 & 3.45 \\
\hline 13 & & 15.35 & 25.4 & 68.34 & 42.94 & 234.36 & 314.04 & 49.99 & 27.59 & 9.99 & 28.34 & 468.71 & 4.04 \\
\hline 14 & & 13.11 & 58.86 & 75.34 & 16.48 & 406.88 & 545.22 & 55.23 & 3.37 & 11.75 & 31.86 & 813.76 & 4.15 \\
\hline 15 & Ngomgham & 22.1 & 42.28 & 64.49 & 22.21 & 337.92 & 452.81 & 42.39 & 0.11 & 0.72 & 22.82 & 675.83 & 3.81 \\
\hline 16 & & 9.39 & 52.42 & 67.26 & 14.84 & 423.61 & 567.64 & 48.87 & 5.45 & 5.39 & 23.78 & 847.22 & 4.24 \\
\hline 17 & & 23.02 & 27 & 72.8 & 45.8 & 244.56 & 327.7 & 49.78 & 22.78 & 8.11 & 31.13 & 489.11 & 4.3 \\
\hline 18 & & 9.78 & 53.2 & 73.24 & 20.04 & 402.57 & 539.44 & 53.46 & 10.26 & 9.98 & 29.76 & 805.13 & 4.18 \\
\hline 19 & Ntamulung & 15.67 & 41.5 & 61.92 & 20.42 & 310.32 & 415.83 & 46.25 & 4.75 & 2.77 & 18.44 & 620.64 & 4.04 \\
\hline 20 & & 17.21 & 56.5 & 74.21 & 17.71 & 391.57 & 524.7 & 57.00 & 0.50 & 13.52 & 30.73 & 783.14 & 3.41 \\
\hline
\end{tabular}

TABle 4: Summary statistics of the soil moisture characteristics in the Bamenda wetlands $(n=20)$.

\begin{tabular}{|c|c|c|c|c|c|c|c|c|c|c|c|c|}
\hline Parameters & $\begin{array}{l}\text { HW } \\
(\%)\end{array}$ & $\begin{array}{l}\text { WP } \\
(\%)\end{array}$ & $\begin{array}{l}\text { FC } \\
(\%) \\
\end{array}$ & $\begin{array}{c}\text { AWR } \\
(\%)\end{array}$ & $\begin{array}{c}\text { AWC } \\
(\mathrm{mm} / \mathrm{m})\end{array}$ & $\begin{array}{c}\text { RAW } \\
(\mathrm{mm} / \mathrm{m})\end{array}$ & $\begin{array}{l}\text { CW } \\
(\%)\end{array}$ & $\begin{array}{l}\text { UW } \\
(\%)\end{array}$ & $\begin{array}{c}\text { WHC } \\
(\mathrm{mm} / \mathrm{m})\end{array}$ & $\begin{array}{c}D \\
(\mathrm{dm} / \mathrm{m})\end{array}$ & $\begin{array}{l}\text { GW } \\
(\%)\end{array}$ & $\begin{array}{l}\mathrm{AC} \\
(\%)\end{array}$ \\
\hline Minimum & 7.20 & 22.14 & 48.16 & 11.13 & 215.83 & 289.21 & 29.04 & 0.11 & 431.66 & 2.65 & 0.72 & 6.49 \\
\hline Maximum & 23.02 & 58.86 & 75.34 & 45.80 & 423.61 & 567.64 & 57.00 & 27.59 & 847.22 & 4.44 & 13.52 & 31.86 \\
\hline Mean & 13.72 & 44.80 & 67.00 & 22.20 & 339.85 & 45540 & 48.09 & 8.48 & 679.70 & 3.83 & 7.46 & 24.76 \\
\hline $\mathrm{SD}$ & 4.87 & 11.16 & 7.09 & 10.16 & 62.87 & 84.24 & 6.65 & 8.25 & 125.73 & 0.45 & 4.08 & 6.89 \\
\hline $\mathrm{CV}$ & 36.00 & 25.00 & 11.00 & 46.00 & 18.00 & 18.00 & 14.00 & 97.00 & 18.00 & 12.00 & 55.00 & 28.00 \\
\hline Skew & 0.59 & -0.66 & -1.15 & 1.27 & -0.48 & -0.48 & -1.21 & 1.33 & -0.48 & -1.06 & -0.14 & -1.19 \\
\hline Kurtosis & -0.53 & -0.45 & 1.10 & 0.63 & -0.70 & -0.70 & 2.16 & 0.47 & -0.70 & 0.81 & -1.40 & 0.97 \\
\hline K-S stat & 0.13 & 0.13 & 0.16 & 0.20 & 0.13 & 0.13 & 0.12 & 0.25 & 0.13 & 0.22 & 0.13 & 0.20 \\
\hline
\end{tabular}

HW: hygroscopic water; WP: permanent wilting point; FC: field capacity; AWR: available water reserve; AWC: available water content; RAW: readily available water; CW: capillary water; UW: unavailable water; WHC: water-holding capacity; D: weighting depth; AC: air content; GW: gravity water; CV: coefficient of variation; SD: standard deviation; K-S stat: Kolmogorov-Smirnov statistics.

TABle 5: Correlation amongst soil physical characteristics and soil organic carbon.

\begin{tabular}{|c|c|c|c|c|c|c|c|c|c|}
\hline Soil properties & $D_{p}$ & $D_{b}$ & Sand & Silt & Clay & $\mathrm{RF}$ & SOC & Silt/clay ratio & SOCS \\
\hline$D_{p}$ & 1 & & - & - & - & - & - & - & - \\
\hline$D_{b}$ & 0.2 & 1 & - & - & - & - & - & - & - \\
\hline Sand & 0.38 & -0.12 & 1 & - & - & - & - & - & - \\
\hline Silt & 0.22 & -0.02 & -0.32 & 1 & & - & - & - & - \\
\hline Clay & $-0.52^{*}$ & -0.11 & $-0.63^{* *}$ & -0.41 & 1 & - & - & - & - \\
\hline $\mathrm{RF}$ & 0.11 & -0.2 & -0.25 & 0.24 & -0.08 & 1 & - & - & - \\
\hline SOC & $-0.49^{*}$ & -0.4 & -0.31 & -0.31 & $0.69^{* *}$ & -0.26 & 1 & - & - \\
\hline Silt/clay ratio & $0.46^{*}$ & 0.1 & 0.17 & $0.80^{* *}$ & $-0.84^{* *}$ & 0.22 & $-0.64^{* *}$ & 1 & - \\
\hline SOCS & $-0.48^{*}$ & $0.49^{*}$ & -0.36 & -0.40 & $0.53^{* *}$ & -0.32 & $-0.65^{* *}$ & $0.98^{* *}$ & 1.00 \\
\hline
\end{tabular}

${ }^{*}$ Correlation is significant at the 0.05 level; ${ }^{* *}$ correlation is significant at the 0.01 level.

3.3. Soil Water Characteristic Curves. Soil moisture characteristic curves enabled establishing the relationship between the volumetric water content and soil matric potential of the studied soil (Figure 5), using water retention data (Table 8). The curves revealed a sigmoid shape which sloped gently from the HW to UW, steepened more from UW to
AW, and became gentle from gravity water to complete pore saturation. The Gleysols of Mile 4 Nkwen showed the lowest water retention curve while those of Ngomgham displayed the highest ones (Figure 5). The soils attained full water saturation $(\mathrm{HW}+\mathrm{AWC}+\mathrm{GW}+\mathrm{AC})$ at a range of $57.68 \%$ of dry soil (Mile 4 Nkwen) to $91.70 \%$ of dry soil (Ngomgham). 
TABLe 6: Pearson linear correlation coefficients amongst soil moisture characteristics $(n=20)$.

\begin{tabular}{|c|c|c|c|c|c|c|c|c|c|c|}
\hline Soil properties & $\mathrm{HW}$ & WP & $\mathrm{FC}$ & AWR & AWC & RAW & $\mathrm{CW}$ & UW & WHC & $\mathrm{D}$ \\
\hline HW & 1.00 & - & - & - & - & - & - & - & - & - \\
\hline WP & -0.32 & 1.00 & - & - & - & - & - & - & - & - \\
\hline $\mathrm{FC}$ & 0.36 & 0.45 & 1.00 & - & - & - & - & - & - & - \\
\hline AWR & $0.59^{*}$ & $-0.78^{* *}$ & 0.20 & 1.00 & - & - & - & - & - & - \\
\hline AWC & -0.36 & $0.95^{* *}$ & $0.46 *$ & $-0.73^{* *}$ & 1.00 & - & - & - & - & - \\
\hline RAW & -0.36 & $0.95^{* *}$ & $0.46^{* *}$ & $-0.73 * *$ & $0.99^{* *}$ & 1.00 & - & - & - & - \\
\hline $\mathrm{CW}$ & 0.25 & 0.37 & $0.92^{* *}$ & 0.24 & 0.38 & 0.38 & 1.00 & - & - & - \\
\hline UW & 0.14 & $-0.78^{* *}$ & 0.04 & $0.88^{* *}$ & $-0.68^{* *}$ & $-0.68^{* *}$ & 0.14 & 1.00 & - & - \\
\hline WHC & -0.36 & -0.36 & $0.46^{*}$ & $-0.73^{* *}$ & 1.00 & 1.00 & 0.38 & $-0.68^{* *}$ & 1.00 & - \\
\hline $\mathrm{D}$ & 0.27 & 0.13 & $0.74^{* *}$ & 0.37 & 0.29 & 0.36 & $0.70^{* *}$ & 0.30 & 0.29 & 1.00 \\
\hline$D_{p}$ & 0.12 & $0.54^{*}$ & 0.31 & 0.37 & $0.52^{*}$ & $0.52^{*}$ & 0.35 & 0.38 & $-0.52^{*}$ & -0.17 \\
\hline$D_{b}$ & 0.02 & -0.37 & -0.09 & 0.34 & -0.08 & -0.08 & -0.01 & 0.41 & -0.08 & $0.47^{*}$ \\
\hline Sand & 0.04 & $-0.57^{*}$ & $-0.48^{*}$ & 0.28 & $-0.54^{*}$ & $-0.54^{*}$ & $-0.47^{*}$ & 0.33 & $-0.54^{*}$ & $0.48^{*}$ \\
\hline Silt & 0.29 & $-0.48^{*}$ & -0.05 & $0.49^{*}$ & -0.45 & -0.45 & -0.06 & 0.42 & -0.44 & $-0.51^{*}$ \\
\hline Clay & -0.34 & $0.81^{* *}$ & 0.27 & $-0.70 *$ & $0.81^{* *}$ & $0.81^{* *}$ & 0.19 & $-0.66^{* *}$ & $0.81^{* *}$ & 0.22 \\
\hline $\mathrm{RF}$ & 0.15 & -0.01 & 0.39 & 0.29 & -0.10 & -0.10 & 0.33 & 0.26 & -0.10 & 0.07 \\
\hline SOC & -0.35 & $0.85^{* *}$ & 0.39 & $-0.66^{*}$ & $0.81^{* *}$ & $0.81 * *$ & 0.31 & $-0.61^{* *}$ & $0.81^{* *}$ & 0.25 \\
\hline Silt/clay ratio & 0.44 & 0.04 & -0.06 & -0.08 & 0.07 & 0.07 & -0.20 & -0.35 & 0.07 & -0.14 \\
\hline SOCS & -0.35 & $0.96^{* *}$ & 0.45 & $-0.82^{* *}$ & $0.94^{* *}$ & $0.94^{* *}$ & 0.37 & $-0.79^{* *}$ & $0.94^{* *}$ & 0.05 \\
\hline
\end{tabular}

${ }^{*}$ Correlation is significant at the 0.05 level; ${ }^{* *}$ correlation is significant at the 0.01 level.

TABle 7: Principal component analysis generated based on factor loading $(n=20)$.

\begin{tabular}{|c|c|c|c|}
\hline Soil properties & $\mathrm{PC1}$ & PC2 & PC3 \\
\hline HW & -0.36 & 0.48 & 0.23 \\
\hline WP & 0.98 & -0.01 & 0.11 \\
\hline $\mathrm{FC}$ & 0.42 & 0.84 & 0.28 \\
\hline AWR & -0.79 & 0.59 & 0.07 \\
\hline AWC & 0.97 & 0.08 & -0.13 \\
\hline RAW & 0.97 & 0.08 & -0.13 \\
\hline CW & 0.36 & 0.81 & 0.29 \\
\hline UW & -0.76 & 0.44 & -0.05 \\
\hline WHC & 0.97 & 0.08 & -0.13 \\
\hline $\mathrm{D}$ & 0.20 & 0.86 & -0.23 \\
\hline$D_{p}$ & -0.61 & -0.11 & 0.19 \\
\hline$D_{b}$ & -0.28 & 0.32 & -0.72 \\
\hline Sand & -0.59 & -0.38 & 0.74 \\
\hline Silt & 0.11 & -0.57 & 0.51 \\
\hline Clay & 0.87 & --0.01 & -0.24 \\
\hline $\mathrm{RF}$ & -0.10 & 0.46 & 0.33 \\
\hline SOC & 0.89 & -0.01 & 0.08 \\
\hline Total loading ${ }^{\mathrm{a}}$ & 11.75 & 6.5 & 1.94 \\
\hline$\%$ variance explained & 45.12 & 18.93 & 9.68 \\
\hline Cumulative \% variance explained & 45.12 & 18.93 & 73.73 \\
\hline
\end{tabular}

RF: coarse fragments; extraction method: principal component analysis.

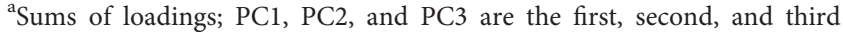
principal components.

The height of the water characteristic curves shows a mean increasing trend such that Ngomgham $>$ below Foncha $>$ Mulang $>$ Ntamulung $>$ Mile 4 Nkwen.

\section{Discussion}

4.1. Soil Moisture Storage Capacity of Gleysols as Affected by Physical Properties and SOC. The Gleysols of the Bamenda wetlands were reddish brown, wet, and waterlogged, with

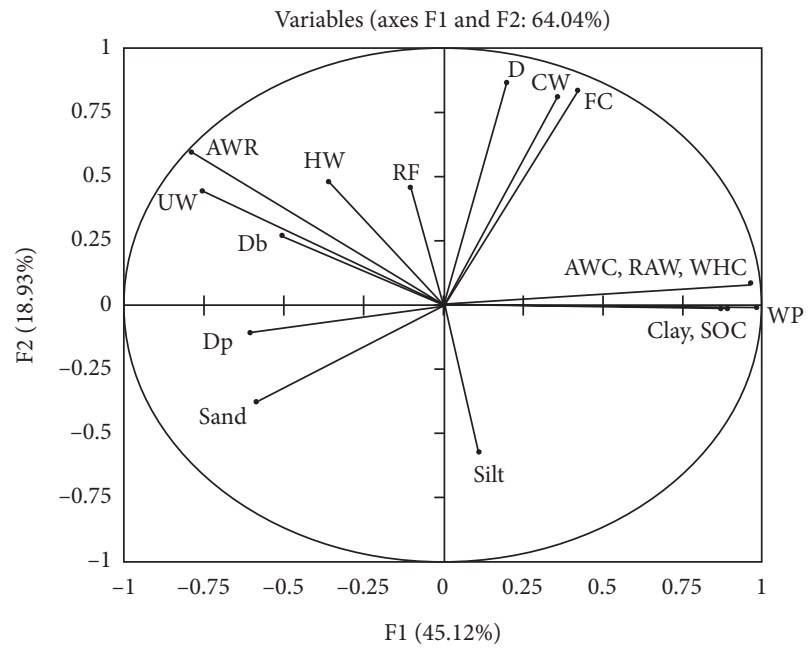

FIgURE 4: Graphical representation of the first two principal components of soil and moisture characteristics. Extraction method: principal component analysis $(n=20)$.

reddish yellow and blue patches in the more waterlogged areas. The surface aspect of the studied Gleysols is shown in Figure 6 . These properties are common to all wetland soils [28]. The massive structure and high density of these soils can be attributed to high clay content. The high clay content in turn made the soils stick to farm tools. The sand/silt ratio is an index of weathering intensity according to Sharma et al. [36]. All the ratio values were greater than $0.45 \%$, typical of moderate weather. The silt/clay ratio of the Gleysols was $>0.15$, indicating that the soils are relatively young or $>0.20$ portraying a high degree of weathering potential [37]. These indices agreed with values of alluvial floodplain Gleysols [13].

The plant-available water content of the Bamenda Gleysols was very high according to GEPPA [34]. Such high 


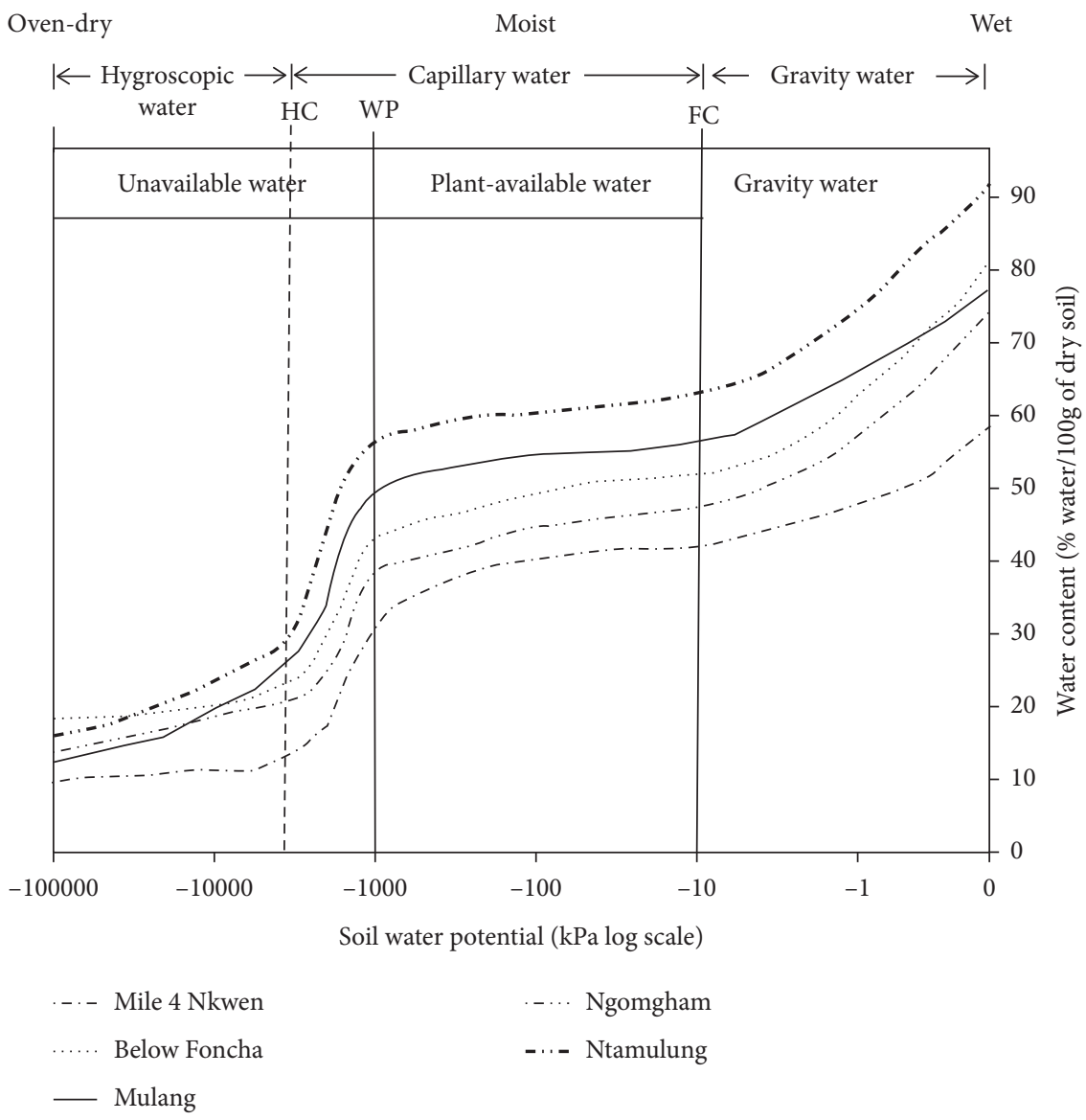

Figure 5: Mean moisture retention curve of the Gleysols from different studied sites in the Bamenda wetlands. HC: hygroscopic coefficient; WP: moisture content at permanent wilting point; FC: moisture content at field capacity.

TABLE 8: Cumulative soil moisture contents (in \% of dry soil) used to model the water characteristic curves of the Gleysols in the Bamenda wetlands.

\begin{tabular}{lccccc}
\hline Properties & HW & UW & UW + AWR & UW + AWR + GW & UW + AWR + GW + AC \\
\hline Mile 4 Nkwen $(n=3)$ & 8.17 & 21.59 & 27.18 & 41.48 & 57.68 \\
Below Foncha $(n=4)$ & 16.40 & 21.86 & 43.72 & 52.02 & 80.72 \\
Mulang $(n=5)$ & 11.73 & 23.67 & 49.39 & 64.11 & 78.49 \\
Ngomgham $(n=5)$ & 16.6 & 28.46 & 56.91 & 47.53 & 91.70 \\
Ntamulung $(n=3)$ & 14.22 & 19.39 & 38.78 & 52.20 & 73.84 \\
Mean $(n=20)$ & 13.72 & 23.00 & 44.60 & 76.50 \\
\hline
\end{tabular}

HW: hygroscopic water content; UW: unavailable water content; AWR: available water reserve; CW: capillary water content; GW: gravity water content; AC: air content; $n$ : number of samples.

values have already been reported in some wetland soils of North Cameroon [13]. Also, comparatively lower available water contents have also been reported elsewhere, such as $110.00 \mathrm{~mm} / \mathrm{m}$ in Australia [38], $125.00 \mathrm{~mm} / \mathrm{m}$ in Sudan [39], and $230.00 \mathrm{~mm} / \mathrm{m}$ in India [40]. The difference is often attributed to soil texture, climate, and topographic positions $[9,10]$.

The WHC values for soils from $95 \%$ of the sampling points of the Bamenda Gleysols were very high $(>600 \mathrm{~mm} / \mathrm{m})$ and comparable with values of some wetland soil in North Cameroon [13]. Thus, Gleysols dominated by silt and sand have low WHC values while clay-rich ones show high WHC values [38]. The high values of RAW observed in most of the studied soils are a function of the soil texture and the organic matter contents of the Gleysols.

The air capacity of the studied Gleysols was high compared to the optimum root aeration value of $10.00 \%$ and the critical value of $5.00 \%$ required for optimum plant performance [40]. Such high air contents indicate high free water potential. So, most of the water that infiltrates into pores is retained in the profiles and induces soil impermeability, surface ponding, poor aeration, and floods in the rainy season [41]. 
Table 9: List of Ramsar sites in Cameroon [15].

\begin{tabular}{|c|c|c|c|c|c|c|c|}
\hline $\begin{array}{l}\mathrm{S} / \\
\mathrm{N}\end{array}$ & Site & $\begin{array}{l}\text { Ramsar } \\
\text { identifier }\end{array}$ & $\begin{array}{c}\text { Designation } \\
\text { date }\end{array}$ & Region & Geographic coordinates & $\begin{array}{l}\text { Altitude } \\
(\mathrm{m})\end{array}$ & $\begin{array}{c}\text { Surface area } \\
\left(\mathrm{km}^{2}\right)\end{array}$ \\
\hline 1 & Waza-Logone floodplain & 1609 & $26 / 05 / 2006$ & $\begin{array}{l}\text { Extreme } \\
\text { North }\end{array}$ & $\begin{array}{c}11^{\circ} 37^{\prime} 59^{\prime} \text { North, } \\
14^{\circ} 37^{\prime} 01^{\prime} \text { East }\end{array}$ & 300 & 6000 \\
\hline 2 & Barombi-Mbo Lake & 1643 & $8 / 10^{\prime} 2006$ & South west & $\begin{array}{c}4^{\circ} 40^{\prime} 01^{\prime} \text { North } \\
9^{\circ} 22^{\prime} 59^{\prime} \text { East }\end{array}$ & $301-400$ & 4.15 \\
\hline 3 & $\begin{array}{c}\text { Cameroon section of the } \\
\text { Sangha River }\end{array}$ & 1739 & $2 / 02 / 2008$ & East & $\begin{array}{c}1^{\circ} 49^{\prime} 59^{\prime} \text { North, } \\
16^{\circ} 01^{\prime} 59^{\prime} \text { East }\end{array}$ & $350-700$ & 62 \\
\hline 4 & $\begin{array}{c}\text { Cameroon section of Lake } \\
\text { Chad }\end{array}$ & 1903 & $2 / 02 / 2010$ & $\begin{array}{l}\text { Extreme } \\
\text { North }\end{array}$ & $\begin{array}{l}12^{\circ} 46^{\prime} 01^{\prime} \text { North, } \\
14^{\circ} 18^{\prime} 00^{\prime} \text { East }\end{array}$ & $160-280$ & 125 \\
\hline 5 & Rio Del Rey Estuary & 1908 & $20 / 05 / 2010$ & South West & $\begin{array}{c}4^{\circ} 37^{\prime} 01^{\prime} \text { North, } \\
8^{\circ} 43^{\prime} 01^{\prime} \text { East }\end{array}$ & 5 & 1650 \\
\hline 6 & $\begin{array}{l}\text { Cameroon section of the } \\
\text { Ntem River }\end{array}$ & 2067 & $5 / 06 / 2012$ & South & $\begin{array}{l}2^{\circ} 22^{\prime} 44^{\prime} \text { North, } \\
10^{\circ} 33^{\prime} 14^{\prime} \text { East }\end{array}$ & $400-526$ & 398.48 \\
\hline 7 & Ebogo Humid Zone & 2028 & 6/05/ 2012 & Centre & $\begin{array}{l}3^{\circ} 23^{\prime} 10^{\prime} \text { North, } \\
11^{\circ} 29^{\prime} 20^{\prime} \text { East }\end{array}$ & $630-670$ & 30.97 \\
\hline
\end{tabular}

The soil moisture characteristics increased considerably from upstream at Mile 4 Nkwen to downstream at Ngomgham, Mulang, below Foncha, and Ntamulung. This might be related to transport and deposition of fine earth material from upstream to downstream and to the geomorphological configuration of the studied site or even to specific soil characteristics like the mineralogical composition of the clayey fraction. Also, several soil internal factors may be responsible for the variation in the soil moisture retention curve per site such as nonuniformity of pores, contact angle difference, and entrapped air in pore space [42].

The capillary water of the wetland soils was high as this water fraction is held to soil particles by weak surface tension forces of soil particles and is thus available to plants. During conditions of water stress (particularly during the dry season), capillarity plays a vital role in maintaining crop performance. The soil water loss is faster at the surface than at depth causing a higher water tension at the surface than at depth $[43,44]$. It causes a higher water tension at the surface than at depth and this creates a water capillary current which moves from base to surface and, hence, water rises to the surface to be available to plants $[45,46]$. The FC and WP are primarily influenced by irregular pore geometry and discontinuity, and variations in texture and mineralogy [47-50].

In this study, clay content of the soils correlated best with the moisture characteristics, more than any other property. The clay and SOC contents, probably linked together as revealed by their significant positive correlation, favor the occurrence of micropores and menisci that generate capillary forces. Thus, they increase the specific surface area of the soil matrix and, consequently, water adsorption [48]. Although silt/clay ratio displays no significant correlation with soil moisture characteristics, it negatively strongly correlates with SOC. The size and structure of clay particles were more suitable for association with SOM molecules than the size and the structure of bigger soil particles [49]. The clay and SOC contents are indispensable in the water and nutrient retention for plants based on their high specific surface area [50]. Sand and coarse fragments contents tend to increase soil particle density thereby increasing macroporosity and reducing microporosity, hence lowering the soil capacity to retain water [51]. Thus, low correlation coefficients between sand and coarse fragments contents and WHC are documented $[52,53]$; meanwhile, the negative correlation between SOC and silt content is not in line with some results [44].

The statistical analysis of the studied soil properties followed a log-normal distribution as revealed by the coefficient of kurtosis and skewness indicating possible anthropogenic disturbances. Under natural grasslands, many soil variables tend to conform to normal distribution due to the homogenization effect of biotic factors [54]. Following irrigation or rainfall, that saturates the soil, making its water content higher than FC, there should normally be a downward movement of water by gravity action. Infiltration is related to hydraulic conductivity that leads to decrease in soil moisture content as infiltration leads to soil water loss.

4.2. Implications of the Gleysols Characteristics on Agricultural Management Strategies. In the Bamenda wetlands, water losses often attain WP in the dry season making plantavailable water contents low. This condition of water stress has been reported to cause drastic decrease in yields in wetlands [55]. Therefore, for irrigation, the "plant readily available water" constitutes the ideal operating range of soil moisture for irrigation management $[29,56]$. Thus, irrigation scheduling should involve the replacement of depleted water not higher than the FC to avoid waterlogging in these soils as drainage and/or deep percolation is poor. But since the soils are flooded in the rainy season, it implies that their water content is above the FC and thus necessitating the drainage of excess water during farming in the rainy season. The soil water characteristic curves become an indispensable to design irrigation schedules, especially in the dry season during moisture deficiency or to drain excess water in the rainy season [57-59].

To achieve high yields without creating excess drainage, it is necessary to know the crop readily available to be cultivated. After readily available water has been used, plant roots cannot easily extract water and nutrients from the soil 


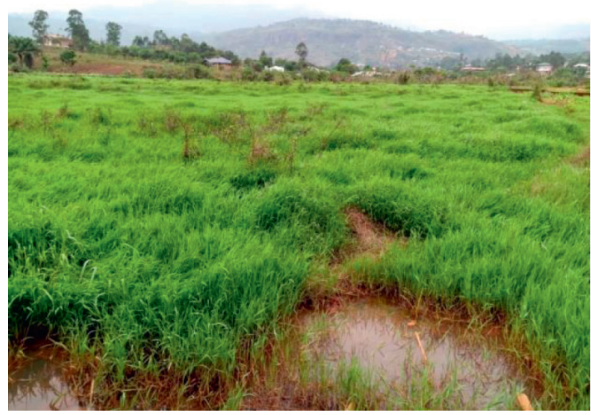

(a)

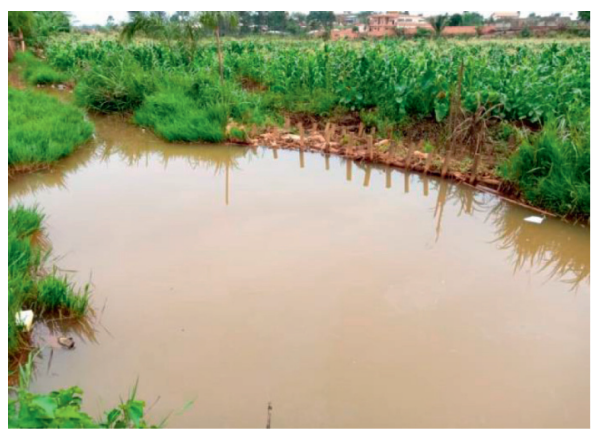

(c)

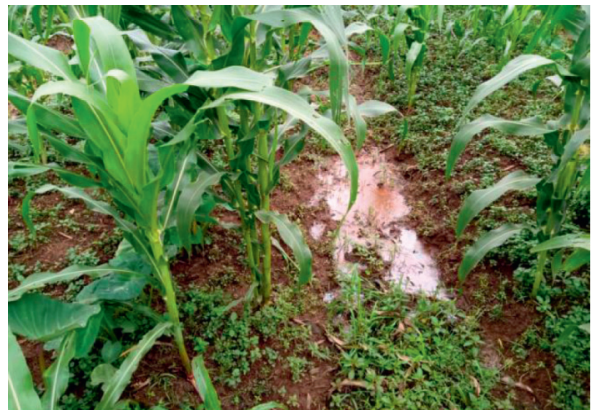

(e)

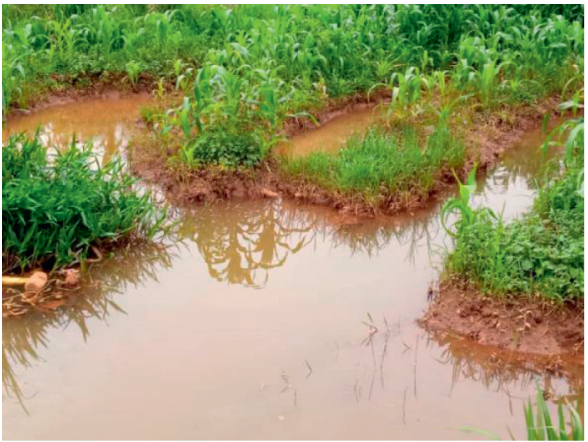

(b)

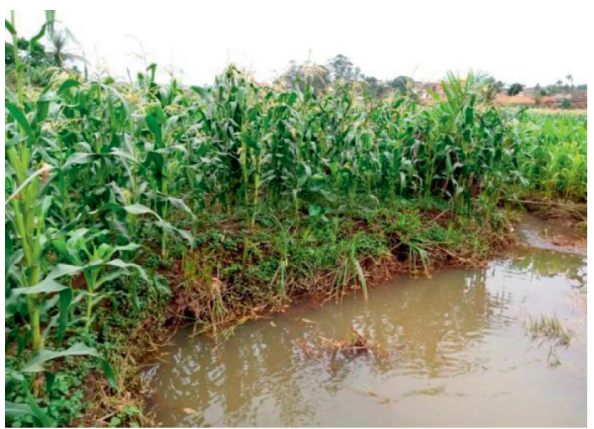

(d)

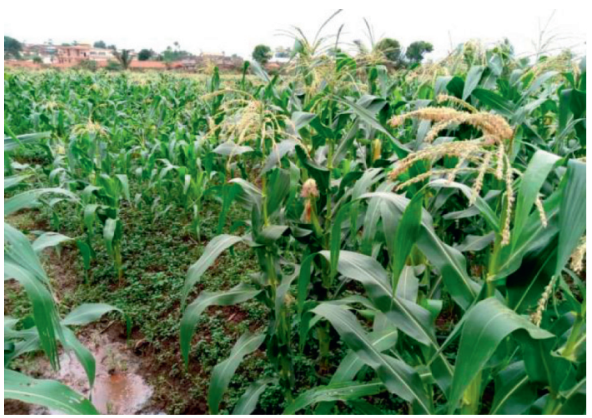

(f)

FIGURE 6: Photographs of wetland ecosystems in Nkwen (Bamenda). (a) Wetland with grassed vegetation; (b) water retained in furrows of raised ridges; $(c, d)$ channeling of water into farmlands for irrigation; $(e, f)$ healthy maize crops cultivated in the wetlands of Bamenda.

and this is the time to irrigate or refill point. The drier the soil is, the more water it needs to return to field capacity. Thus, in irrigation, FC and refill point are critical values for the correct use of many of the soil water monitoring.

The high clay content of the Gleysols in the Bamenda wetlands makes tillage and weed control in these areas difficult due to the presence of water and sticky nature of soils to farm tools. The high bulk density of the Gleysols is very high $\left(1.6 \mathrm{~g} \cdot \mathrm{cm}^{-3}\right)$ compared to the optimum value $\left(1.33 \mathrm{~g} \cdot \mathrm{cm}^{-3}\right)$ for root penetration but also close to the upper limit $\left(1.75 \mathrm{~g} \cdot \mathrm{cm}^{-3}\right)$ for root growth, and is therefore a limiting factor to agriculture [60]. High bulk density implies that the soils are not well aerated as most of the pores are saturated with water during wet conditions.

The highly significant correlation between clay and organic matter contents reveals that both are linked together to form organo-mineral complexes, and thus, the SOC is being protected by soil matrix. These two soil colloids play a vital role in the retention of water and nutrients for crop needs as revealed by their high correlation with most of the moisture characteristics. The high SOC implies a high cation exchange capacity (CEC). The overall CEC of SOC and clay contents favors the retention and availability of nutrients to maintain crop production in those Gleysols [60-62].

Particle size distribution also conditions chemical nutrient supply [63]. Most of the studied Gleysols samples have clay plus silt content greater than $35 \%$; this indicates poor nutrient assimilation by plants. A correlation has also been established between particle size distribution and yields [63]. The (silt + sand)-to-total earth ratios of the Gleysols were very high ( $>>35 \%)$ relative to the ratio range of 15 to $35 \%$ necessary for optimum yields and indicate potentially poor yields for a majority of tropical crops [63].

The SOCS of the Bamenda wetlands Gleysols is very high (>200 Mg.ha ${ }^{-1}$ ) as such wetlands, especially floodplains, are often very productive [4]. Such ecosystems have the ability of 
sequestering and storing carbon through photosynthesis and organic matter accumulation in soils and plant biomass thereby offering the opportunity for regaining lost productivity especially under agricultural systems. The properties of these studied soils could be similar to those of some Ramsar sites in Cameroon, although with some site specific features. Table 9 shows different Ramsar sites in Cameroon.

\section{Conclusion}

In Bamenda City (Northwest Cameroon), population increase has led to considerable lawless occupation of wetlands especially as these areas are very fertile and support yearround agriculture. Land use is often done without necessary technical know-how of sustainable land management techniques. This work was focused on the determination of moisture characteristics of Gleysols in the Bamenda wetlands and to establish a link between them and selected soil characteristics affecting crop production.

The major findings revealed that the Gleysols showed very high organic carbon contents and very high soil organic carbon stocks implying a high level of carbon sequestration. Major constraints of the soils to farming were clay plus silt contents, massive structure, and waterlogging. The moisture properties revealed very high water-holding capacity and very high plant-available water. The particle density and coarse fragments and sand contents correlated negatively with the soil moisture retention characteristics and could be reducing the soil's water-holding capacity. The soil moisture characteristics curves were sigmoid-shaped and their heights decreased from upstream to downstream probably portraying increase of finer material with fluvial transport distant.

The present work might have been limited in terms of the inadequate number of samples studied. Further research is necessary on these wetland soils of the northwest region of Cameroon to evaluate their potential risk of degradation based on a higher number of samples. Also, the results presented in this work might have been biased based on the fact that the tests were conducted solely in the laboratory. In the future, measurements of water storage capacity of these soils should be done directly in the field using more accurate methods such as electrical resistance and tensiometric and heat-diffusion methods. Irrigation schedules on this these soils should involve the replacement of depleted water with water amounts not exceeding the FC to avoid waterlogging in these soils as drainage and/or deep percolation is poor. Adapted crops like lowland rice could also be introduced to extend the surfaces of rice cultivation in the zone.

\section{Data Availability}

Data can be made available on request.

\section{Conflicts of Interest}

The authors declare no conflicts of interest.

\section{References}

[1] W. J. Rawls, T. J. Gish, and D. L. Brakensiek, "Estimating soil water retention from soil physical properties and characteristics," Advances in Soil Science, vol. 16, pp. 213-234, SpringerVerlag, New York Inc, NY, USA, 1991.

[2] E. Kellner and S. Halldin, "Water budget and surface-layer water storage in a Sphagnum bog in central Sweden," $\mathrm{Hy}$ drological Processes, vol. 16, no. 1, pp. 87-103, 2002.

[3] R. M. Khalid and H. A. K. Ahmed, "Nature of soil-water characteristics curves (SWCC) for soils from Anbar Governorate," Anbar Journal of Engineering Sciences, vol. 3, no. 1, pp. 61-80, 2010.

[4] The Ramsar Convention on Wetlands, "Climate Change and Wetlands, Resolution X.24," in Proceedings of the 10th Meeting of the Conference of the Parties to the Convention on Wetlands, Changwon, Republic of Korea, October 2008, https://www.ramsar.org/document/resolution-x24-climatechange-and-wetlands.

[5] J. Vopravil, P. Formánek, and T. Khel, "Comparison of the physical properties of soils belonging to different reference soil groups," Soil and Water Research, vol. 16, pp. 29-38, 2021.

[6] USDA, Soil Survey Manual, USDA, Washington, D. C, USA, 2017.

[7] S. R. Carpenter, W. A. Brock, and P. Hanson, "Resilient management comments on," Ecological and Social Dynamics in Simple Models of Ecosystem Management Conservation Ecology, Resilience Alliance, vol. 3, no. 2, Wisconsin, USA, 1999.

[8] K. E. Saxton and W. J. Rawls, "Soil water characteristic estimates by texture and organic matter for hydrologic solutions," Soil Science Society of America Journal, vol. 70, no. 5, pp. 1569-1578, 2006.

[9] P. A. Tamfuh, A. H. Chotangui, A. H. Chotangui et al., "Land characteristics and agricultural suitability status along a toposequence in Santa, Bamenda Highlands, Cameroon," Journal of Atmospheric \& Earth Science, vol. 4, no. 1, pp. 1-9, 2020.

[10] A. Kagou Dongmo, C. S. Guedjeo, P. Azinwi Tamfuh et al., "Geochemical and geotechnical characterization of soils developed on volcanic rocks in the Bamenda Mountain (Cameroon volcanic line)," International Journal of Advanced Geosciences, vol. 6, no. 2, pp. 184-194, 2018.

[11] B. Minasny and A. E. Hartemink, "Predicting soil properties in the tropics," Earth-Science Reviews, vol. 106, no. 1-2, pp. 52-62, 2011.

[12] D. Baros and A. Albernaz, "Possible impacts of climate change on wetlands and its biota in the Brazilian Amazon," Brazilian Journal of Biology, vol. 74, no. 4, pp. 810-820, 2014.

[13] P. Azinwi Tamfuh, E. Djoufac Woumfo, E. Temgoua, A. Boukong, and D. Bitom, "Moisture moisture-related properties and agricultural management strategies of the Benue floodplain Vertisols in North Cameroon," African Journal of Agricultural Research, vol. 13, no. 33, pp. 17301746, 2018.

[14] IPCC (Intergovernmental Panel on Climate Change), "Climate change 2013: the physical science basis," in Contribution of Working Group I to the Fifth Assessment Report of the Intergovernmental Panel on Climate Change, T. F. Stocker, D. Qin, G.-K. Plattner et al., Eds., Cambridge University Press, Cambridge, UK, 2013, http://www.ipcc.ch/report/ar5/wg1/.

[15] Ramsar Sites Information Service, Annotated List of Wetlands of International Importance Cameroon, Ramsar Sites Information Service, Gland, Switzerland, 2016, https://rsis.ramsar. org/fr/ris-search/?language $=$ fr\&f[0] regioncountry_fr_ss\%3A Cameroon. 
[16] A. Magha, M. A. Tita, G. D. Kouankap, P. Wotchoko, A. Tabot, and V. K. B. Kamgang, "Physico-chemical and bacteriological characterization of spring and well water in Bamenda III (NW region, Cameroon)," American Journal of Environmental Protection, vol. 4, no. 3, pp. 163-173, 2015.

[17] S. S. Kometa, "Wetlands exploitation along the Bafoussam Bamenda road axis of the Western Highlands of Cameroon," Journal of Human Ecology, vol. 41, no. 1, pp. 25-32, 2013.

[18] E. M. Nyambod, "Environmental consequences of rapid urbanisation: Bamenda city, Cameroon," Journal of Environmental Protection, vol. 1, no. 1, pp. 15-23, 2010.

[19] M. A. Tita, G. N. Tsala, and K. V. B. Kamgang, "Levels of metals in huckleberry (Solanum scabrum) grown along the Mezam river banks Bamenda, North-West Cameroon: implications for crops growth and human consumption," Syllabus Review, vol. 2, no. 2, pp. 69-78, 2011.

[20] C. Acho, "Human interference and environmental instability addressing the environmental consequences of rapid urban growth in Bamenda," Environment and Urbanization, vol. 10, no. 2, pp. 161-174, 1998.

[21] A. G. Asongwe, P. K. Y. Bernard, and A. S. Tening, "Spatial variability of selected physico-chemical properties of soils under vegetable cultivation in urban and peri-urban wetland gardens of Bamenda municipality Cameroon," African Journal of Agricultural Research, vol. 11, no. 2, pp. 74-86, 2016.

[22] N. A. Mofor, N. E. B. Tamungang, K. Mbene, N. B. Yuhinwenkeh, and F. B. Nchofua, "Trace element status and environmental implications of soils and Zea mays from farmed dumpsites in the Bamenda metropolis, North west Cameroon," Applied and Environmental Soil Science, vol. 2020, Article ID 8861102, 9 pages, 2020.

[23] C. S. Guedjeo, A. Kagou Dongmo, F. Ngapgue et al., "Natural hazards along the Bamenda escarpment and its environs: the case of landslide, rock fall and flood risks," Journal of Geology and Mining Research, vol. 2, pp. 15-26, 2012.

[24] R. N. Afungang, C. A. Nkwemoh, and R. Ngoufo, "Spatial modelling of landslide susceptibility using logistic regression model in the Bamenda Escarpment zone, NW Cameroon," International Journal of Innovative Research and Development, vol. 6, no. 12, pp. 187-199, 2017.

[25] P. Kamgang, E. Njonfang, G. Chazot, and F. Tchoua, "Géochimie et géochronologie des laves felsiques des monts Bamenda (ligne volcanique du Cameroun)," Comptes Rendus Geoscience, vol. 339, no. 10, pp. 659-666, 2007.

[26] E. N. Ndenecho and B. Eze, "Geomorphic and anthropogenic factors influencing landslides in the Bamenda Highlands (North West province, Cameroon)," Journal of Applied Social Sciences, vol. 4, no. 1, pp. 15-26, 2004.

[27] L. Van Reeuwijk, "Procedures for Soil Analysis," in Sulitjelmafeltets geologi og petrografi, Norge sGeologisk eUndersokelse, T. Vogt, Ed., vol. 121, pp. 1-560, ISRIC-FAO, Wageningen, Netherlands, 1927.

[28] FAO (Food and Agriculture Organization), Guidelines for Soil Description, a Framework for International Classification, Correlation and Communication, FAO, Rome, Italy, 2006.

[29] B. Jabiol, L'eau dans le sol, FIF-ENGREF, Paris, France, 2001.

[30] K. S. Grewal, G. D. Buchan, and P. J. Tonkin, "Estimation of field capacity and wilting point of some New Zealand soils from their saturation percentages," New Zealand Journal of Crop and Horticultural Science, vol. 18, no. 4, pp. 241-246, 1990.

[31] M. Vilain, La Production Végétale”, éditeur LAVOISIER/ TEC ET DOC, collection Agriculture d'aujourd'hui, vol. 2, Paris, France, 1997, https://www.unitheque.com/Livre /Lavoisier-tec_et_doc/Agriculture_d_aujourd_hui/La_pro duction_vegetale_Volume_2-33593.html.
[32] H. Baize and B. Jabiol, Guide Pour la Description des sols, Masson, Paris, France, 1er edition, 1995.

[33] J. Lozet and C. Mathieu, Dictionnaire de Science du Sol, vol. 8, Karstologia, Paris, France, 2eme edition, 1986.

[34] GEPPA (Groupe d'Étude des Problèmes en Pédologie Appliquée), Synthèse des travaux de la Commission de cartographie 1971-1981, GEPPA (Groupe d'Étude des Problèmes en Pédologie Appliquée), Paris, France, 1981.

[35] B. D. Reetashree, B. Das, G. Yam, P. Pankaj, and O. P. Tripathi, "Modeling water holding capacity using readily available soil characteristics," Journal of Agricultural Research, vol. 8, pp. 347-355, 2019.

[36] R. P. Sharma, P. Raja, and B. P. Bhaskar, "Pedogenesis and mineralogy of alluvial soils from semi-arid South Eastern part of Rajasthan in Aravalli range, India," Journal of the Geological Society of India, vol. 95, no. 1, pp. 59-66, 2020.

[37] W. G. Sombroek and I. S. Zonneveld, Ancient Dune Fields and Fluviatiledeposits, Soil Survey Institute of Wageningen, Wageningen, Netherlands, 1971.

[38] H. C. T. Stace, G. D. Hubble, R. Brewer et al., A Handbook of Australian Soils, Soil Science Society of America, Relim Technical Publications, Glenside, SA, Adelaide, Australia, 1968.

[39] T. N. Jewitt, R. D. Law, and K. J. Virgo, "Vertisol soils of the tropics and sub-tropics: their management and use," Outlook on Agriculture, vol. 10, no. 1, 1979.

[40] E. A. Gardner, K. J. Coughlan, and D. M. Silburn, "Soil water measurement and management of vertisols in Queensland (Australia)," in Proceedings of the Conference on the Management of Vertisols in Sub-saharan Africa, pp. 188-200, Addis Ababa, Ethiopia, August 1987.

[41] S. S. R. Gidigasu and S. K. Y. Gawu, "The mode of formation, nature and geotechnical characteristics of black cotton soils - a review," Standard Scientific Research and Essays, vol. 1, no. 14, pp. 377-390, 2013.

[42] S. L. J. Page, "Effects of the physical properties of two tropical Cotton soils on their permanent wilting point and relative humidity, in relation to survival and distribution of Meloidogyne acronea," Revue Nématologique, vol. 7, no. 3, pp. 227-232, 1984.

[43] G. Haider, T. Hordofa, and B. Endale, "Irrigation water management for cotton on vertisols in the middle awash region of Ethiopia," in Proceedings of the Conference on the Management of Vertisols in Sub-saharan Africa, pp. 166-182, Addis Ababa, Ethiopia, August 1987.

[44] J. M. Reichert, J. A. Albuquerque, D. R. Kaiser, D. J. Reinert, F. Lavarda Urach, and R. Carlesso, "Estimation of water retention and availability in soils of Rio Grande do Sul Revista Brasileira de Ciência do Solo," Sociedade Brasileira de Ciência do Solo Viçosa, vol. 33, no. 6, pp. 1547-1560, 2009.

[45] J. M. Reichert, J. A. Albuquerque, D. J. Reinert, J. E. S. Pereza, and A. Da Costa, "Estimating water retention and availability in cultivated soils of Southern Brazil," Geoderma Regional, vol. 21, 2020.

[46] J. L. Costa, V. Aparicio, and A. Cerdà, "Soil physical quality changes under different management systems after 10 years in the Argentine humid pampa," Solid Earth, vol. 6, no. 1, pp. 361-371, 2015.

[47] W. J. Rawls, D. L. Brakensiek, and K. E. Saxton, Estimation of Soil Water Properties, pp. 1316-1328, Transactions American Society of Agricultural Engineers, Michigan, USA, 1982.

[48] D. Hillel, Environmental Soil Physics, Academic Press, San Diego, USA, 1998. 
[49] W. G. Sombroek and I. S. Zonneveld, Ancient Dune Fields and Fluviatile Deposits in the Rima-Sokoto River Basin (NW Nigeria), Netherlands Soil Survey Institute, Wageningen, Netherlands, 1971.

[50] W. J. Rawls, Y. A. Pachepsky, J. C. Ritchie, T. M. Sobecki, and H. Bloodworth, "Effect of soil organic carbon on soil water retention," Geoderma, vol. 116, no. 1-2, pp. 61-76, 2003.

[51] M. Mecke, C. J. Westman, and H. Ilvesniemi, "Water retention capacity in coarse Podzol profiles predicted from measured soil properties," Soil Science Society of America Journal, vol. 66, no. 1, pp. 1-11, 2002.

[52] M. Van den Berg, E. Klamt, L. P. Van Reeuwijk, and W. G. Sombroek, "Pedotransfer functions for the estimation of moisture retention characteristics of ferralsols and related soils," Geoderma, vol. 78, no. 3-4, pp. 161-180, 1997.

[53] N. F. B. Giarola, A. P. silva, and S. Imhoff, "Relações entre propriedades físicas e características de solos da Região Sul do Brasil," Revista Brasileira de Ciência do Solo, vol. 26, pp. 885-893, 2002.

[54] R. G. D. Steel and J. H. Torrie, Principles and Procedures of Statistics, A Biometrical Approach, McGraw-Hill, NY, USA, 2nd edition, 1980.

[55] D. G. Fredlund and A. Xing, "Equations for the soil-water characteristic curve," Canadian Geotechnical Journal, vol. 31, no. 4, pp. 521-532, 1994.

[56] A.-M. Laroche, J. Gallichand, R. Lagacé, and A. Pesant, "Simulating atrazine transport with HSPF in an agricultural watershed," Journal of Environmental Engineering, vol. 122, no. 7, pp. 622-630, 1996.

[57] A. D. Costa, J. A. Albuquerque, J. A. D. Almeida, A. D. Costa, and R. V. Luciano, "Pedotransfer functions to estimate retention and availability of water in soils of the state of Santa Catarina, Brazil," Revista Brasileira de Ciência do Solo, vol. 37, no. 4, pp. 889-910, 2013.

[58] M. P. Nguyen, V. K. Le, and C. Wim, Hydrology in a Changing World: Environmental and Human Dimensions Proceedings of FRIEND-Water 2014, vol. 363, pp. 392-398, IAHS Publications, Montpellier, France, 2014.

[59] G. A. Asongwe, P. K. B. Yerima, A. S. Tening, and M. E. Sailieh, "Food security and environmental implications of urban wetlands utilisation as vegetable gardens: the case of Bamenda municipality Cameroon," Journal of Agriculture and Environmental Sciences, vol. 6, no. 1, pp. 66-77, 2017.

[60] H. E. Igbadun, M. A. Oyebode, and A. S. Mohammed, "Evaluation of a simulation model for prediction soil watercharacteristics of selected agricultural fields," Nigerian Journal of Technological Development, vol. 8, no. 1, pp. 61-73, 2011.

[61] T. F. Scherer, D. Franzen, and K. Cihacek, Soil, Water and Plant Characteristics Important to Irrigation, North Dakota State University, Fargo, USA, 2017, http://www.ag.ndsu.edu.

[62] J. Pérez-Rojas, F. Moreno, J. C. Quevedo, and J. Villa, "Soil organic carbon stocks in fluvial and isolated tropical wetlands from Colombia," Catena, vol. 179, pp. 139-148, 2019.

[63] M. Lathan, "Role du facteur sol dans le dévéloppement du cotonnier en Côte d'Ivoire," Cahiers Office de Recherche Scientifique et Technique d'Outre Mer, Série Pédologique, vol. IX, no. 1, pp. 29-42, 1971. 